\title{
СИНТЕЗ И СВОЙСТВА 1,3-ДИЗАМЕЩЕННЫХ МОЧЕВИН И ИХ БИОИЗОСТЕРИЧЕСКИХ АНАЛОГОВ, СОДЕРЖАЩИХ ПОЛИЦИКЛИЧЕСКИЕ ФРАГМЕНТЫ - ИНГИБИТОРОВ РАСТВОРИМОЙ ЭПОКСИДГИДРОЛАЗЫ (SEH)
}

\author{
В.В. Бурмистров, Г.М. Бутов \\ Кафедра химии, технологии и оборудования химических производств, \\ Волгоградский государственный технический университет (филиал), \\ 404131, Россия, г. Волжский, ул. Энгельса, 42а.
}

DOI: 10.19163/MedChemRussia2021-2021-67

E-mail: crus_himself@mail.ru

Одной из фундаментальных проблем современной медицинской химии является разработка субстанций лекарственных препаратов, пригодных для терапии социально опасных заболеваний. 1,3-Дизамещенные мочевины являются одними из наиболее эффективных ингибиторов растворимой эпоксидгидролазы человека (sEH), перспективной мишени в терапии гипертонических, воспалительных и болевых состояний. Однако, большинство известных высокоактивных ингибиторов sEH характеризуются высокой липофильностью и связанной с этим низкой метаболической стойкостью.

В данной работе впервые проведено теоретическое и экспериментальное изучение влияния представительного набора органических соединений, содержащих структурный фрагмент R-(адамантан-1(2)-ил)-X-(0,S,Se)мочевины, на ферменты, клетки, органы и организмы. Определены биологические мишени и механизм действия соединений содержащих привилегированную структуру R-(адамантан-1(2)-ил)-X-(O,S,Se)мочевины, и их функциональных производных другого строения. С использованием синтетической методологии присоединения алифатических, ароматических и жирноароматических изоцианатов и изотиоцианатов к 1,3-дегидроадамантану разработаны новые методы синтеза адамантилсодержащих изоцианатов и изотиоцианатов. Впервые в качестве ингибиторов растворимой эпоксидгидролазы были изучены димеры адамантилированных мочевин, обладающие ингибирующей активностью субнаномолярного диапазона коцентраций за счет образования дополнительных водородных связей в активном центре фермента.

В результате проведённых работ получены новые органические соединения, ингибирующие ферментативную активность растворимых эпоксидгидролаз человека (hsEH, E.C. 3.3.2.10), крыс и мышей в субнаномолярных концентрациях, что может быть использовано для использования в терапии воспалительных, сердечнососудистых и онкологических заболеваний

Работа выполнена при финансовой поддержке Российского научного фонда (грант № 19-73-10002).

$$
-67-
$$

